Kinestetik : Jurnal Ilmiah Pendidikan Jasmani 5 (1) (2021)

Kinestetik : Jurnal Ilmiah Pendidikan Jasmani

https://ejournal.unib.ac.id/index.php/kinestetik/index

DOI : 10.33369/jk.v5i1.13811

\title{
BASIC ANALYSIS FOR TAKING LEARNING POLICIES IN THE PANDEMIC TIME COVID 19
}

\author{
Rahmat Hidayat $^{\mathbf{1}}$, Eko Risdianto ${ }^{2}$, Titin Aprilatutini ${ }^{3}$, Nova Yustisia ${ }^{4}$ \\ ${ }^{1}$ Islamic Education Counseling Guidance, IAIN Curup, Bengkulu, Indonesia \\ ${ }^{234}$ Physics Education, FKIP, Universitas Bengkulu, Bengkulu, Indonesia
}

\section{Article Info}

Article History:

Received: December 2020

Revised: January 2021

Accepted: March 2021

Available online: March 2021

Keywords:

Covid-19, Physical

Education, Practice,

\section{Abstract}

This research aims to conduct a basic analysis of policies on learning services during the Covid-19 period towards practice subjects at IAIN Curup Bengkulu Indonesia. This type of research is Research \& Development (R\&D) by ADDIE at the need assessment stage. Case studies are carried out in the Physical Education course at the Curup state Islamic Institute Bengkulu Indonesia. The population in this study were students of IAIN Curup who took Physical Education courses. The research sample was 238 students. The sampling technique used was the purposive sampling technique and the instrument used was a closed questionnaire. Data were analyzed by using quantitative and qualitative analysis. From this research, it will be obtained the results of an analysis of policies on learning services during the Covid-19 period towards practicing subjects at IAIN Curup. Through this research, it is concluded that most of the policies regarding learning services carried out during the pandemic are still not very good.
Corresponding address: Jln. Dr. AK. Gani. No 1. Ex. Hamlet

Curup. Kec. North Curup. Regency. Rejang

Lebong. 39119

*Email : usrahid@gmail.com
ISSN 2685-6514 (Online)

ISSN 2477-331X (Print) 


\section{INTRODUCTION}

Changes in the world are now entering the era of the 4.0 industrial revolution where information technology has become the basis of human life (Risdianto, 2019). The Industrial Age 4.0 is a term used to refer to an era in which there is a combination of technology that results in physical, biological, and digital dimensions forming a blend that is difficult to distinguish (Putrawangsa \& Hasanah, 2018). The development of the 4.0 industrial revolution appeared marked by the start of the digitalization of the education system which directed every element in the education sector to be able to make adjustments to the rate of change that was occurring (Siahaan et al., 2019). In the education sector, the use of technology is not only a tool used for administrative matters, but it is also possible to use it as a learning tool (Putri et al., 2019). The use of technology as a means of learning is made possible as a learning medium (Marianda et al., 2014). The education system must follow all forms of development that occur because education is one of the main factors that will create a generation of high-minded nations (Risdianto et al., 2020).

The world is currently busy with a coronavirus outbreak. Coronavirus Diseases 2019 (COVID-19) is a new type of disease that has never been previously identified in humans. Common signs and symptoms of COVID-19 infection include symptoms of acute respiratory distress such as fever, cough, and shortness of breath (Goddess, 2020). The National Disaster Management Agency issued decree number 13 A regarding the determination of the emergency period due to the coronavirus. Based on this determination, the Ministry of Education and Culture issued a Circular from the Minister of Education and Culture Number: 36962 / MPK.A / HK / 2020 dated 17 March 2020 concerning Online Learning and Working from Home in the Context of Preventing the Spread of Coronavirus Disease (COVID-19) (Argaheni, 2020). The spread of the Covid-19 epidemic around the world affects millions of students, not except in Indonesia (Shah, 2020). In addition to students, the Covid-19 pandemic also has an impact on teachers, teachers must be able to carry out the learning process effectively online at home. Teachers are required to be able to teach online, teachers' abilities in information technology are needed. Teachers are required to remodel learning plans with online methods, learning methods must also be effective so that the teaching process runs effectively and knowledge can be conveyed (Mastura \& Santaria, 2020). Furthermore, it has an impact on parents, parents again get additional tasks and at the same time become teachers for their children during the online learning process. Parents are required to guide their children during the online learning process (Mastura \& Santaria, 2020).

Physical education is an educational process through physical activity (Jayul \& Irwanto, 2020). The physical education and sports majors are included in the higher education courses that are in great demand by the public. In addition to complex lecture materials, both theory and practice, students also assume that they continue to study at the tertiary level in physical education, students hope that they can maintain their health and, fitness because in the physical education department students are more emphasized to attend lectures in the form of practice whose hope is that in addition to making students skilled, they can also maintain the health and, fitness of students by carrying out practical lecture activities (Setiyawan et al., 2020). However, after the pandemic, the implementation of sports physical education and health 
learning has turned into online learning that cannot be carried out carelessly outdoors without complying with health protocols (Dyah Purnama Sari \& Sutapa, 2020). With various limitations on internet access and operational capabilities on online features, physical education by itself encountered various obstacles and obstacles during the Covid19 pandemic (Herlina \& Suherman, 2020). The constraints experienced by students in health and sports physical education subjects are because sports and health physical education are dominated by psychomotor aspects (physical skills) (Komarudin \& Prabowo, 2020).

Based on the description above, it needs to be done a Basic analysis of policies on learning services during the Covid 19 period on practical subjects, which in this study was a case study conducted in Physical Education courses at IAIN Curup.

\section{METHODS}

\section{Participant}

This study involved students of the Curup State Islamic Institute, located in Rejang Lebong Regency, Bengkulu Province. The sample of this study was 238 students taking Physical Education courses.

\section{Sampling Procedures}

The sampling procedure in this study using the purposive sampling technique.

\section{Materials and Apparatus}

The instrument used in this study was a closed questionnaire used to collect data in the form of student responses.

\section{Data Analysis}

Data analysis in this study was carried out by calculating the percentage of respondents who chose each answer on each item. From the data, it is then explained descriptively so that we can get a conclusion from each item.

\section{RESULT AND DISCUSSION}

From the results of filling out a questionnaire conducted by 238 respondents, the following results were obtained:

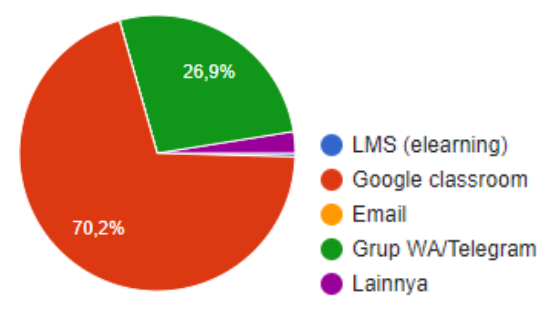

Fig 1. Pie chart

The diagram above shows that google classroom is used more often in the Physical Education course Curup State Islamic Institute. For the material presented by the lecturers, $42.4 \%$ answered instructional videos, 29\% answered presentation slides, 22, 3\% answered sysncronous, and the rest answered e-books. This shows that there are variations in the form of presentation of the material in the Physical Education course.

Delivery of assignments in Physical Education courses $52.1 \%$ answered via wa / telegram group, $33.6 \%$ answered via Google Drive share, 10, 9\% responded by e-mail and the rest answered collected directly. This shows that gryp wa / telegram is most often used for the collection of Physical Education course assignments. Then, for the assessment $80.7 \%$ answered through google classroom, $14.7 \%$ answered direct assessment, and the rest through WA, email and others. This shows that the assessment is at most carried out based on learning in google classroom. For the cellular providers used in lectures, the following results are obtained. 


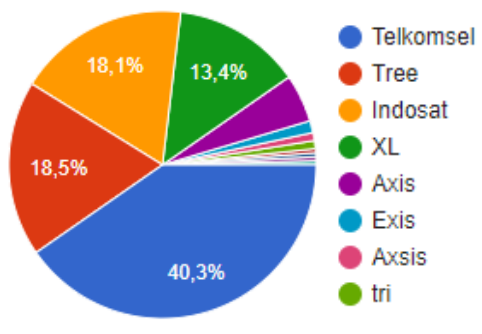

Fig 2. Pie chart

The diagram above shows that there are differences in the providers that students use to take lectures, but most use Telkomsel providers. For the quality of the network at locations, as many as $60.1 \%$ answered not bad, $25.6 \%$ answered well, $11.8 \%$ answered hurriedly, and the rest answered very good and very bad. This shows that most students have a fairly good network in the location where they conduct lecture activities. For data packages used within 1 month, $40.8 \%$ answered 25-50 GB, $18.9 \%$ answered 75$100 \mathrm{~GB}, 18.1 \%$ answered less than $25 \mathrm{~GB}$, $13.9 \%$ answered 50-75 GB and the rest answered above $100 \mathrm{~GB}$. This shows that there are differences in the number of data packages needed by each student. 9\% answered 50-75 GB and the rest answered above $100 \mathrm{~GB}$. This shows that there are differences in the number of data packages needed by each student. 9\% answered 50$75 \mathrm{~GB}$ and the rest answered above 100 GB. This shows that there are differences in the number of data packages needed by each student.

For aspects of campus administration services during online learning, there are two questions listed, namely regarding administrative services and information system services on campus. For administrative services as much as $39.1 \%$ answered well, $35.3 \%$ answered fairly, $17.2 \%$ answered poorly, and the rest answered very well and very poorly. This shows that campus administration services during online learning are still quite good. Meanwhile, for campus information system services, $50 \%$ answered well, $30.3 \%$ answered fairly, $12.6 \%$ answered poorly, and the rest answered very well and very poorly. This shows that the campus information system services during online learning are still quite good.

In this study, data collection was also carried out through a questionnaire made on a Likert scale, where the biggest points were 4 and the smallest was 1 . There were 5 aspects included in this questionnaire, the first was the intrinsic motivation aspect which consisted of 4 statement items. The following is the data from the calculation of the percentage of each statement item on the aspect of intrinsic motivation.

Table 1. Aspect of Intrinsic Motivation

Statement
The Physical Education course is one of the
practice courses that I am interested in among
other practice subjects.
During the Covid 19 pandemic, I found it
difficult to follow courses that should require
the opportunity to practice right away
I feel that practical activities that should be
done face-to-face can better be replaced with
independent practice
I feel that Physical Education courses are not
suitable if done online. So that I am not too
excited compared to college as usual

Table 2. The Result of Calculating the Percentage of Each Item Statement on the Aspect of Intrinsic Motivation

\begin{tabular}{cccc}
\hline $\begin{array}{c}\text { Strongly } \\
\text { agree }\end{array}$ & Agree & Disagree & $\begin{array}{c}\text { Strongly } \\
\text { Disagree }\end{array}$ \\
\hline $29.8 \%$ & $52.5 \%$ & $14.3 \%$ & $3,4 \%$ \\
\hline $44.1 \%$ & 36.1 & $10.9 \%$ & $8.8 \%$ \\
\hline $16.4 \%$ & $16 \%$ & $21.4 \%$ & $46.2 \%$ \\
\hline $44.1 \%$ & $30.7 \%$ & $13 \%$ & $12.2 \%$ \\
\hline
\end{tabular}

The table above shows that most respondents agree that the Physical Education course is one of the most popular practice subjects among other practice subjects. Most students find it 
difficult to follow courses that should require the opportunity to practice directly, students also disagree and even strongly disagree on doing independent practice. Most students feel that Physical Education courses are not suitable if they are done online so they are not too excited compared to lectures as usual. The next aspect is Self Efficacy (individual belief). In this aspect, there are 5 statements. The following is the data from the calculation of the percentage of each statement item on the aspect of Self Efficacy (individual belief).

Table 3. Aspect of Self Efficacy

\begin{tabular}{l}
\hline \multicolumn{1}{c}{ Statement } \\
\hline I am not confident that I will get the best score at \\
this Physical Education Program even though it \\
is done online \\
I am sure I can master the knowledge and skills \\
given in this course even though it is done online \\
I can complete assignments promptly. Although \\
sometimes there are Network constraints \\
I am confident that I will be able to complete \\
various tests in Physical Education courses which \\
are conducted online \\
The skills that I will acquire in this online \\
Physical Education course will be the same as if \\
done offline because the learning strategies given \\
by the lecturer are correct
\end{tabular}

Table 4. The Result of Calculating the Percentage of Each Item Statement on the Aspect of Self Efficacy

\begin{tabular}{cccc}
\hline $\begin{array}{c}\text { Strongly } \\
\text { agree }\end{array}$ & Agree & Disagree & $\begin{array}{c}\text { Strongly } \\
\text { Disagree }\end{array}$ \\
\hline $20.2 \%$ & $49.2 \%$ & $17.2 \%$ & $13.4 \%$ \\
\hline $10.1 \%$ & $21 \%$ & $35.7 \%$ & $33.2 \%$ \\
\hline $21.8 \%$ & $32.8 \%$ & $25.6 \%$ & $19.7 \%$ \\
\hline $9.2 \%$ & $27.7 \%$ & $35.3 \%$ & $22.7 \%$ \\
\hline $7.6 \%$ & $23.5 \%$ & $33.2 \%$ & $35.7 \%$ \\
\hline
\end{tabular}

The table above shows that most students lacking confidence will get the best scores in this Physical Education Program even though it is done online. Most students are also not sure that they can master the knowledge and skills given in this course even though they are done online. Not all students are confident that they can complete assignments on time. Most students feel unable to complete various tests in Physical Education courses which are conducted online. Students disagree and even strongly disagree with the statement of skills that will be obtained in this online Physical Education course will be the same as if it is done offline because the learning strategy given by the lecturer is correct.

The next aspect, namely Self Determination. This aspect consists of 5 statements. The following is the result of calculating the percentage of each item in the Self Determination aspect.

Table 5. Aspect Self Determination

\begin{tabular}{l} 
Statement \\
\hline In online learning that has been carried out in this \\
Physical Education course, strategies have been \\
used to learn well \\
\hline I can use the maximum time on the Physical \\
Education course even though it is done online \\
I feel able to prepare myself in a Physical \\
Education course that is done online \\
Even though I was able to adapt, I found it \\
difficult to follow practical learning courses that \\
were carried out online \\
Readiness and seriousness in learning in Physical \\
Education courses during this pandemic are \\
important to get maximum learning outcomes
\end{tabular}

Table 6. The Result of Calculating the Percentage of Each Item Statement on the Aspect Self Determination

\begin{tabular}{cccc}
\hline $\begin{array}{c}\text { Strongly } \\
\text { agree }\end{array}$ & Agree & Disagree & $\begin{array}{c}\text { Strongly } \\
\text { Disagree }\end{array}$ \\
\hline $9.2 \%$ & $45.8 \%$ & $31.1 \%$ & $13.9 \%$ \\
\hline $7.6 \%$ & $36.1 \%$ & $34.5 \%$ & $21.8 \%$ \\
\hline $5.9 \%$ & $30.7 \%$ & $38.7 \%$ & $24.8 \%$ \\
\hline $36.1 \%$ & $31.5 \%$ & $18.1 \%$ & $14.3 \%$ \\
\hline $39.5 \%$ & $45.4 \%$ & $10.5 \%$ & $4.6 \%$ \\
\hline
\end{tabular}

The table above shows that almost half of the respondents disagree or even strongly disagree with the statement that the online learning that has been carried out in this Physical Education course has 
used strategies to learn well. Most respondents disagree and even strongly disagree that they can use the maximum time in the Physical Education course even though it is done online. Students feel unable to prepare themselves for the Physical Education course which is carried out online.

The next aspect, namely Motivation Grade. This aspect consists of 3 statements. The following is the result of calculating the percentage of each item in the Grade Motivation aspect.

Table 7. Aspect of the Motivation Grade

\begin{tabular}{l}
\hline \multicolumn{1}{c}{ Statement } \\
\hline I still doubt the assessment system for Physical \\
Education courses if it is done online \\
Getting good grades is essential for the smooth \\
running of my studies \\
Even though it is done online, I will follow this \\
Physical Education course well to get the \\
maximum score
\end{tabular}

Table 8. The Result of Calculating the Percentage of Each Item Statement on the Aspect of the Motivation Grade

\begin{tabular}{cccc}
\hline $\begin{array}{c}\text { Strongly } \\
\text { agree }\end{array}$ & Agree & Disagree & $\begin{array}{c}\text { Strongly } \\
\text { Disagree }\end{array}$ \\
\hline $29.4 \%$ & $42.4 \%$ & $18.9 \%$ & $9.2 \%$ \\
\hline $63 \%$ & $26.5 \%$ & $6.3 \%$ & $4.2 \%$ \\
\hline $45.4 \%$ & $31.5 \%$ & $13.9 \%$ & $9.2 \%$ \\
\hline
\end{tabular}

The table above shows that most students are unsure of the physical education course assessment system when it is done online. According to respondents, good grades are important for the smooth running of their studies, so most of them answered that they would follow this Physical Education course well to get maximum grades.

The last aspect in this questionnaire is Career Motivation. There are 2 statements on this aspect. The following is the result of calculating the percentage of each item in the Career Motivation aspect.
Table 9. Aspect of Career Motivation

\begin{tabular}{l}
\hline Statement \\
\hline Learning this Physical Education course will \\
help improve my skills, physicality and health \\
in the future \\
A strong body can help me get a good job in the \\
future
\end{tabular}

Table 10. The Result of Calculating the Percentage of Each Item Statement on the Aspect of Career Motivation

\begin{tabular}{cccc}
\hline $\begin{array}{c}\text { Strongly } \\
\text { agree }\end{array}$ & Agree & Disagree & $\begin{array}{c}\text { Strongly } \\
\text { Disagree }\end{array}$ \\
\hline $55.9 \%$ & $34.5 \%$ & $4.2 \%$ & $5.5 \%$ \\
\hline $49.6 \%$ & $41.2 \%$ & $5.9 \%$ & $3,4 \%$ \\
\hline
\end{tabular}

The table above shows that most students strongly agree that studying this Physical Education course will help improve their skills, physicality and health in the future and they also strongly agree that a strong body can help them get a good job in the future.

\section{CONCLUSION}

The results of the basic analysis of policies on learning services during the Covid-19 period on practice courses (Physical Education subjects) at the Curup State Islamic Institute, whose data were obtained through filling out a questionnaire, showed that most policies on learning services were still not very good.

\section{ACKNOWLEDGEMENT}

Acknowledgments are conveyed to all respondents who are students Curup State Islamic Institute who took the Physical Education course that had helped the process of filling out the questionnaire to obtain the data needed in this study. 


\section{REFERENCES}

Argaheni, NB (2020). Systematic Review: The Impact of Online Lectures During the COVID-19 Pandemic on Indonesian Students. PLACENTUM: Health Scientific Journal and Its Applications, 8 (2), 99. https://doi.org/10.20961/placentum.v8i 2.43008

Dewi, WAF (2020). Impact of COVID-19 on Online Learning Implementation in Primary Schools. Educative: Journal of Educational Sciences, 2 (1), 55-61. https://doi.org/10.31004/edukatif.v2i1.8 9

Dyah Purnama Sari, \& Sutapa, P. (2020). The Effectiveness of Online Distance Learning During the COVID-19 Pandemic in Sports and Health Physical Education (PJOK) Subjects. Pediatric Critical Care Medicine, 19-29.

Herlina, H., \& Suherman, M. (2020). The Potential of Learning Physical Education, Sports and Health (Corner) Amid the Corona Virus Disease (Covid) -19 Pandemic in Elementary Schools. Tadulako Journal Sport Sciences And Physical Education, 8 (1), 1-7. http://jurnal.untad.ac.id/jurnal/index.ph $\mathrm{p} / \mathrm{PJKR} /$ article/view/16186

Jayul, A., \& Irwanto, E. (2020). Online Learning Model as an Alternative to the Process of Physical Education Learning Activities in the Middle of the Covid-19 Pandemic Achmad. Journal of Recreational Health Education, 6 (2), 190-199.

Komarudin, \& Prabowo, M. (2020). Students' Perceptions of Online Learning in Sports and Health Subjects during the Covid-19 Pandemic. Sports Scientific Magazine (MAJORA), 26 (2), 56-66.

Marianda, G., Johar, A., \& Risdianto, E. (2014). The Design of Learning Media Based on Interactive Multimedia, the Concept of Style in the Physics Subject of Class VIII Junior High Schools. Recursive Journal, 2 (2), 112-120.

Mastura, \& Santaria, R. (2020). The Impact of the Covid-19 Pandemic on the Teaching Process for Teachers and Students Introduction. Journal of Teacher Studies and Learning, 3 (2), 289-295.

Putrawangsa, S., \& Hasanah, U. (2018). Integration of Digital Technology in Learning in the Industrial Age 4.0 Study from a Mathematics Learning Perspective. Tatsqif Journal, 16 (1), 4254. https://doi.org/10.20414/jtq.v16i1.203

Putri, RM, Risdianto, E., \& Rohadi, N. (2019). Development of Interactive Learning Media Using Adobe Captivate on Simple Harmonic Motion Material. Physics Coil Journal, 2 (2), 113-120. https://doi.org/10.33369/jkf.2.2.113120

Risdianto, E. (2019). Leadership in the World of Education in Indonesia in the Era of the Industrial Revolution 4.0. 1-12.

Risdianto, E., Bengkulu, U., Fitria, J., Bengkulu, U., Johan, H., Bengkulu, U., \& Macariola, JS (2020). Teacher's Perception of Thermodynamic Law Module Developed in Training through Student's Critical Thinking Skills. Journal of Social Work and Science Education, 1 (1), 78-86.

Setiyawan, Kresnapati, P., \& Setiawan, DA (2020). Analysis of online lectures by PJKR students at the University of PGRI Semarang as a result of the COVID-19 pandemic. Indonesian Journal of Physical Education, 1 (1), 25-32.

Siahaan, AD, Medriati, R., \& Risdianto, E. (2019). Development of Basic Physics Practicum Guide Using Augmented Reality Technology on Geometric Electrical and Optical Circuits. Kumparan Physics Journal, 2 (2), 91-98. https://doi.org/10.33369/jkf.2.2.91-98

Shah, RH (2020). The Impact of Covid-19 on Education in Indonesia: Schools, Skills, and the Learning Process. SALAM: Journal of Social and Cultural Affairs Syar-I, 7 (5), 395-402. https://doi.org/10.15408/sjsbs.v7i5.153 14 